Supplementary Information

\title{
In Situ and Real-Time ATR-FTIR Temperature-dependent Adsorption Kinetics Coupled with DFT calculations of Dimethylarsinate and
} Arsenate on Hematite Nanoparticles

\author{
Sara Soldoozy ${ }^{\S}$, Anthony Trinh ${ }^{\S}$ James D. Kubicki ${ }^{\ddagger}$, and Hind A. Al-Abadleh ${ }^{\S *}$

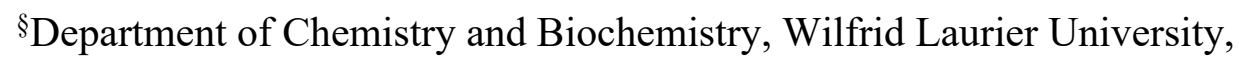 \\ Waterloo, ON N2L 3C5, Canada \\ tDepartment of Geological Sciences, The University of Texas at El Paso, \\ El Paso, TX 79968, USA
}

*Corresponding author email: halabadleh@wlu.ca

Journal: Langmuir

Prepared: April 2, 2020

Table of Contents (13 pages)

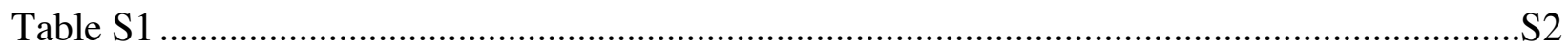

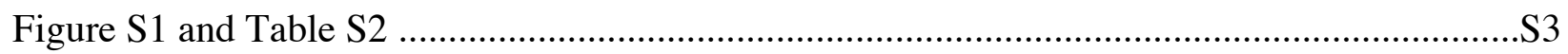





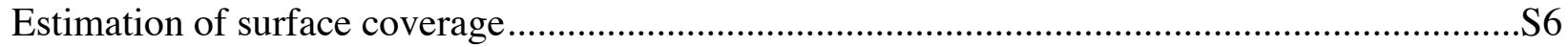

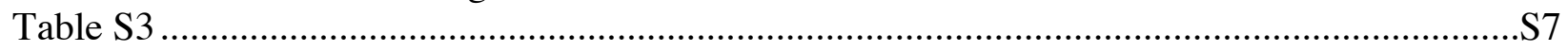

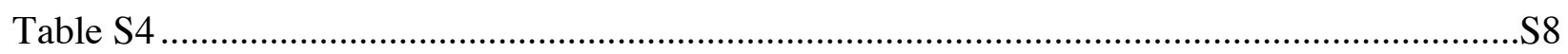

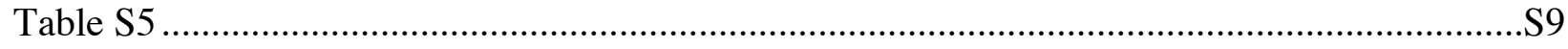

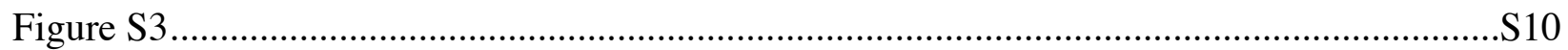

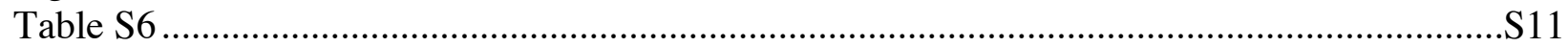

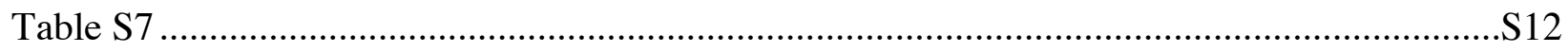



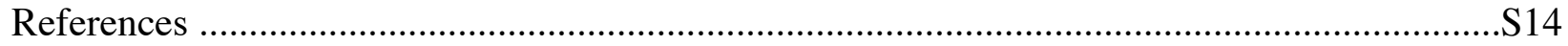


Table S1. Structure and $\mathrm{pK}_{\mathrm{a}}$ of the arsenicals used in the study.

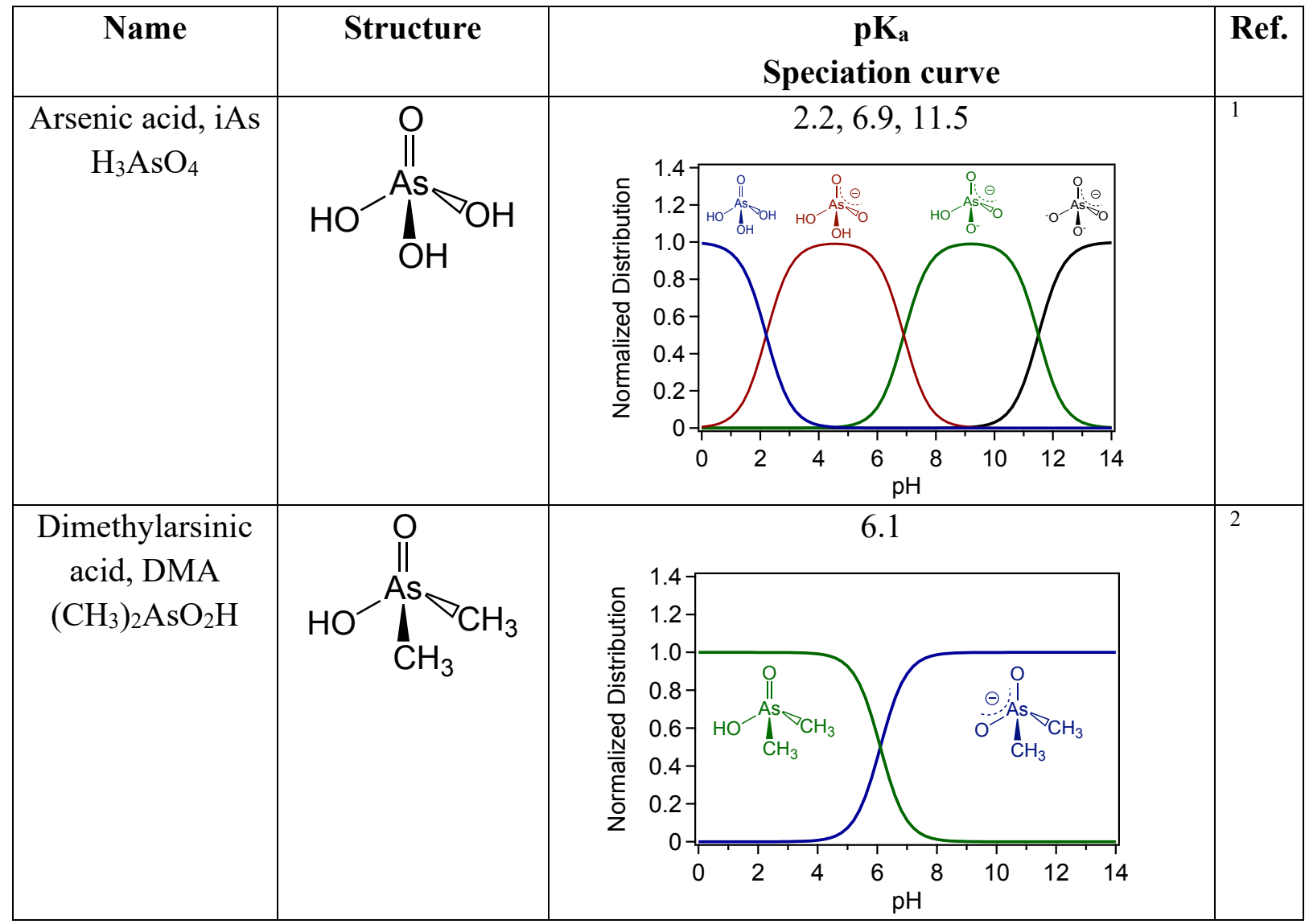



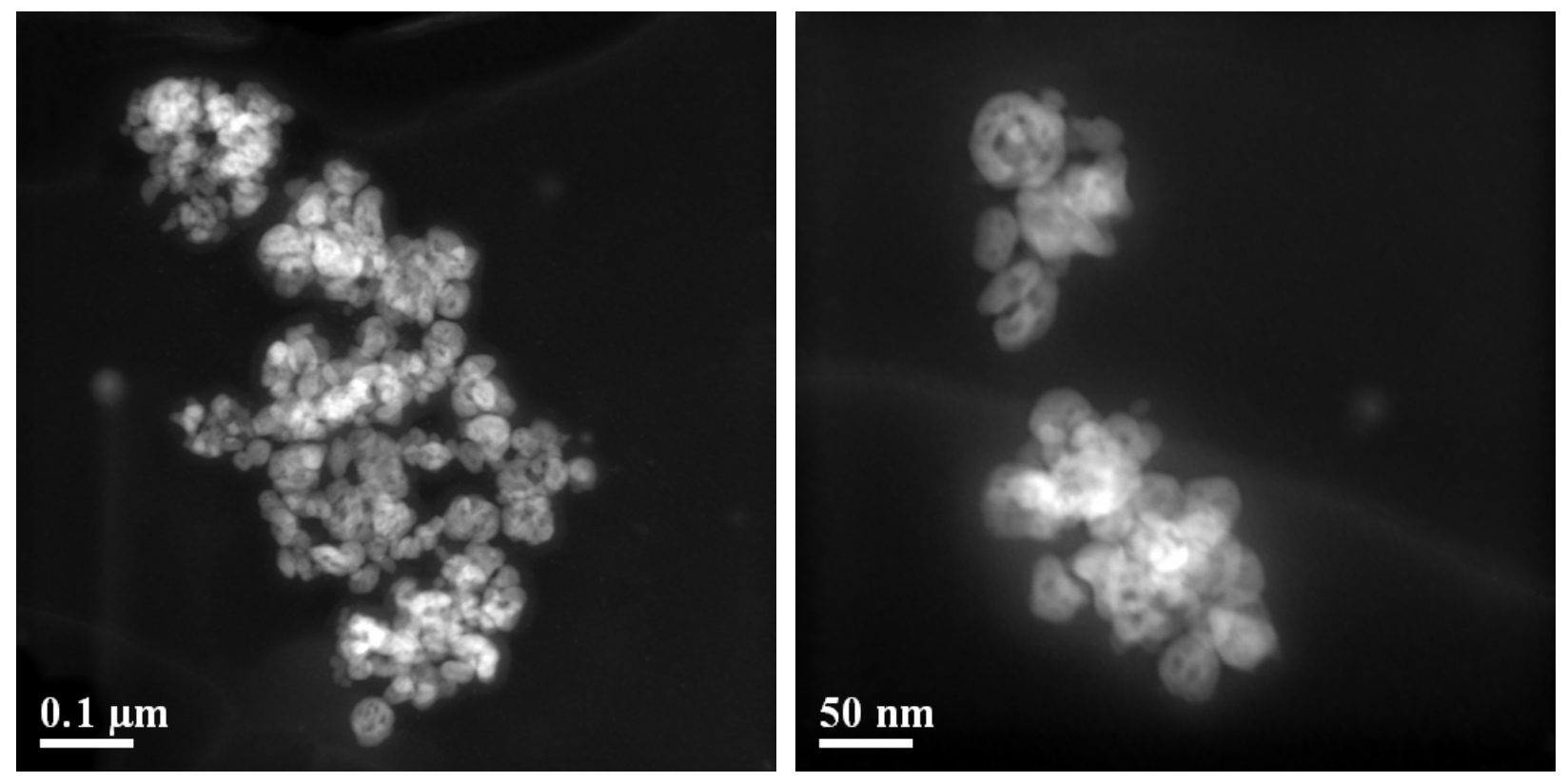

Figure S1: (a) Representative STEM images of hematite nanoparticles used in this study (Canadian Centre for Electron Microscopy, McMaster University)

Table S2: Density of hydroxyl groups per reference ${ }^{3}$ on the hematite faces identified in particles shown in Figure S1 from high resolution TEM images (Canadian Centre for Electron Microscopy, McMaster University)

\begin{tabular}{|l|c|c|c|c|}
\hline Face & $\begin{array}{c}\text { Singly } \\
\text { coordinated } \\
\left(\text { groups nm }^{-2}\right)\end{array}$ & $\begin{array}{c}\text { Doubly } \\
\text { coordinated } \\
\left(\text { groups nm }^{-2}\right)\end{array}$ & $\begin{array}{c}\text { Triply } \\
\text { coordinated } \\
\left(\text { groups nm }^{-2}\right)\end{array}$ & $\begin{array}{c}\text { Contagious singly } \\
\text { coordinated } \\
\left(\text { groups nm }^{-2}\right)\end{array}$ \\
\hline$(104)$ & 5.3 & 5.3 & 5.3 & - \\
\hline$(113)$ & 4.1 & 4.1 & 8.3 & 2.1 \\
\hline$(110)$ & 5.0 & 5.0 & 5.0 & 2.5 \\
\hline
\end{tabular}

Note: To obtain density in groups $\mathrm{cm}^{-2}$, multiply the above numbers with $10^{14}$. 


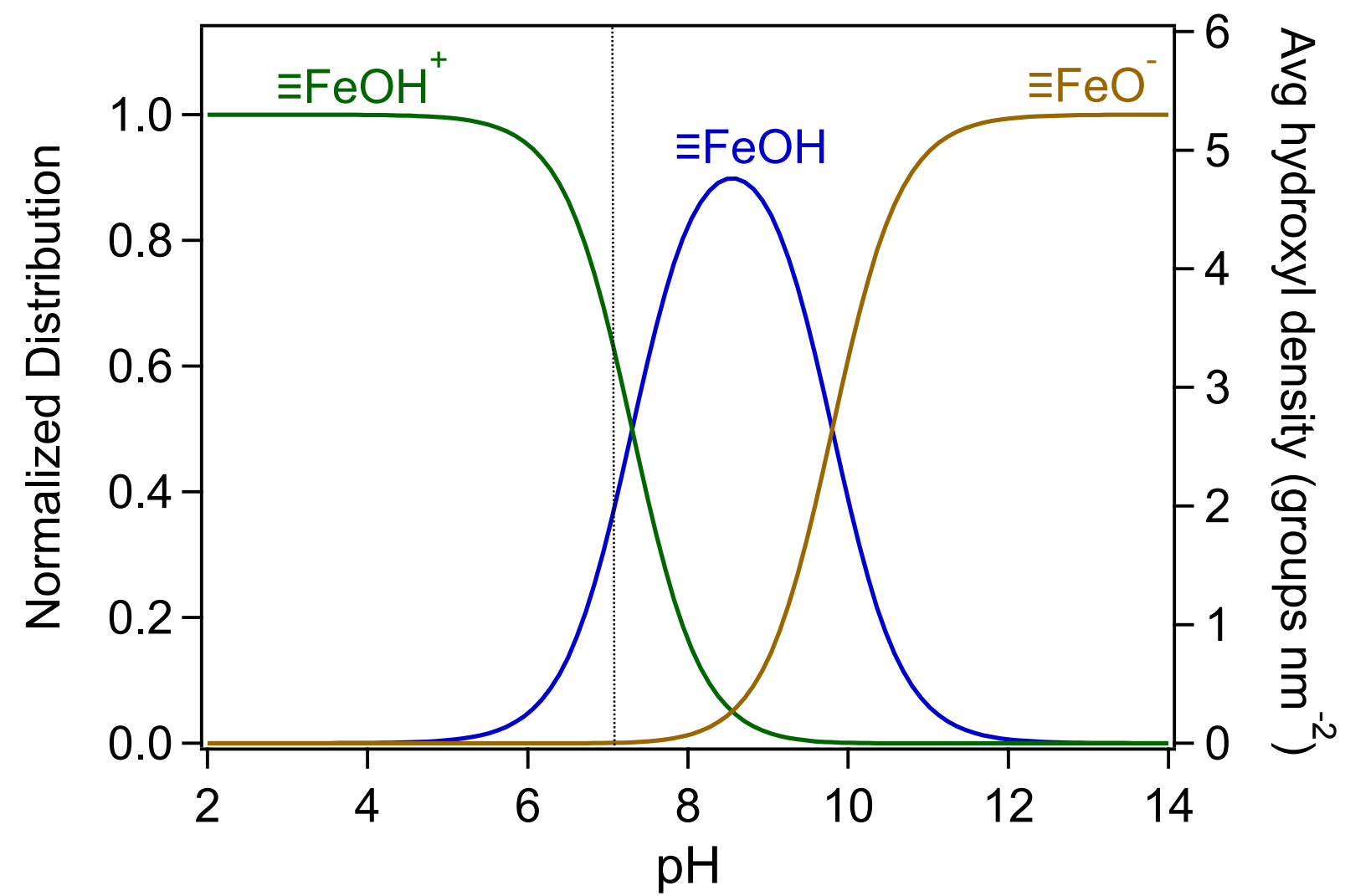

Figure S2: (Left axis) Normalized distribution of hydroxyl group as a function of $\mathrm{pH}$ guided by the experimentally-determined isoelectric point (8.5) for the hematite nanoparticles used here. The $\mathrm{pK}_{\mathrm{a}}$ values are 7.3 and 9.8. (Right axis) average hydroxyl density in groups $\mathrm{nm}^{-2}$ based on values listed in Table S2. The dashed line show the distribution at $\mathrm{pH} 7$ used in our experiments. 


\section{Details on film preparation}

For the preparation of thin hematite films on the ATR internal reflection element (IRE), a slurry of $6 \mathrm{mg}$ of hematite nanoparticles in $1.3 \mathrm{~mL}$ water-ethanol [0.91:0.39 (v/v)] mixture was ultrasonicated (default power, Fisher Scientific Mechanical Ultrasonic Cleaner FS20) for one hour and the slurry obtained was spread over a clean and dry ZnSe ATR crystal. The film was then allowed to dry for $13 \mathrm{~h}$ in air at room temperature under the Al-foil tent. A new freshly deposited film was prepared for each experiment. The thickness (h) of the dry film was estimated to be $\sim 7.5$ $\pm 1.4 \mu \mathrm{m}$, as described in detail in reference ${ }^{4}$. Briefly, $6 \mathrm{mg}$ of the hematite nanoparticle slurry was deposited on a glass slide with similar exposed area as the ATR crystal. The thickness of the dry hematite film was measured at four grooves across the film made with a sharp cutting blade using ultra-fast optical profiler (Wyko NT 3300 Series, Electrochemical Technology Centre, University of Guelph). The bulk density of the deposited hematite dry film was calculated to be $1.1 \mathrm{~g} \mathrm{~cm}^{-3}$ from the measured thickness and the area covered by the film $\left(7.2 \mathrm{~cm}^{2}\right)$.

\section{Collection of ATR-FTIR spectra}

At the beginning of every adsorption kinetic experiment, the jacketed ATR-FTIR flow cell was connected to a water circulating bath to adjust the temperature of the flow cell to the desired value (either $5,15,25,35$ or $50^{\circ} \mathrm{C}$ ). Then, a background $10 \mathrm{mM} \mathrm{NaCl}$ solution was flowed over the film for 90 minutes at the desired temperature to record the background spectrum with 100 averaged scans. Then, a standard solution of the arsenical compound at the concentration of interest at $\mathrm{pH} 7$ was flowed across the same film. Collection of adsorption spectra started automatically as the solution entered the ATR flow cell by averaging 25 scans for up to $10 \mathrm{~min}$, followed by manual collection of spectra every $5 \mathrm{~min}$ for the next $80 \mathrm{~min}$ by averaging 100 scans. The automated 
collection of adsorption spectra was done using a custom-written macro in OMNIC. The collection acquisition times were calculated from the time saved by the computer in the file names. For collecting 25 and 100 averaged scans, the collection times were 16 and 50 s, respectively. Each adsorption single beam spectrum was referenced to the background solution to obtain the absorbance spectra reported here. The ATR-FTIR measurement of each solution was repeated 4 times on a freshly-prepared film to ensure reproducibility. Absorbance of the most intense bands is within experimental error $( \pm 5 \%)$ and band locations are $\pm 2 \mathrm{~cm}^{-1}$.

\section{Estimation of arsenicals surface coverage on porous hematite films from ATR-FTIR spectra}

To quantify the surface coverage by a particular arsenical, baseline-corrected ATR absorbances [i.e., peak height at a given wavenumber, $\mathrm{A}(\tilde{v})]$ of spectral features assigned to surface complexes were used. Values of $\mathrm{A}(\tilde{v})$ were obtained using the height tool in OMNIC software that runs the FTIR spectrometer relative to the absorbance at $2000 \mathrm{~cm}^{-1}$, which has no IR signals from any of the species used in our studies. The derivation of equation S1 for estimating the surface coverage of arsenate and DMA(ads) was reported earlier (see reference ${ }^{5}$ ):

$$
\mathrm{S}\left(\text { molecules } \cdot \mathrm{cm}^{-2}\right)=\frac{\mathrm{A}(\tilde{v})}{\varepsilon(\tilde{v}) \mathrm{N}^{2} \mathrm{~d}_{\mathrm{p}}(\tilde{v}) \rho_{\mathrm{b}} \cdot S \cdot A \cdot B E T}
$$

where $\varepsilon(\tilde{v})$ is molar extinction coefficient of the adsorbate in $\mathrm{cm}^{2}$ molecule ${ }^{-1}$ (listed in Table S3 for each arsenical, which was obtained from the Beer's plot of aqueous phase standard solutions at $\mathrm{pH}$ 7 using a calculated effective pathlength at a given $\tilde{v}$ for water as the sample), $\mathrm{N}$ is the total number of reflections inside the IRE (equals 4.8 for our ATR IRE with effective angle of incidence $\theta=$ $64.4^{\circ}$ using the optical properties of liquid water as described in the Supporting Information of reference ${ }^{6}$ ), $d_{p}$ is the depth of penetration per reflection in cm after accounting for porosity (see 
below), which approximately equals to $d_{e} / N$ (calculated using $\lambda /\left[2 \pi n_{1} \sqrt{\sin ^{2} \theta-\left(n_{2} / n_{1}\right)^{2}}\right], \lambda$ is the wavelength of light $(1 / \tilde{v}), n_{1}$ and $n_{2}$ are the refractive indices of IRE $(2.4$ for $\mathrm{ZnSe})$ and the sample, respectively), $\rho_{\mathrm{b}}$ is the bulk density of the deposited hematite film (equals $1.1 \mathrm{~g} \mathrm{~cm}^{-3}$ as detailed in text), and $S . A . B E T$ is the specific surface area of the hematite particles (equals $4.4 \times 10^{5}$ $\left.\mathrm{cm}^{2} \mathrm{~g}^{-1}\right)$

In the presence of a porous hematite film, the value of $n_{2}$ has to account for the porosity and the presence of solvent in the pores. ${ }^{7}$ A volume-weighed average of the refractive index of the particles $\left(\mathrm{n}_{2}^{\prime}\right)$ is calculated using $\mathrm{n}_{2}^{\prime}=\mathrm{F}_{\mathrm{v}} \cdot \mathrm{n}_{\mathrm{par}}+\left(1-\mathrm{F}_{\mathrm{v}}\right) \cdot \mathrm{n}_{\mathrm{H}_{2} \mathrm{O}(1)}$, where $\mathrm{F}_{\mathrm{v}}=\rho_{\mathrm{b}}\left(\mathrm{gcm}^{-}\right.$ $\left.{ }^{3}\right) / \rho_{\text {true }}\left(\mathrm{gcm}^{-3}\right), \mathrm{n}_{\mathrm{par}}$ is the particle refractive index $(2.9$ for hematite $)$ and $\mathrm{n}_{\mathrm{H}_{2} \mathrm{O}(\mathrm{l})}=1.3{ }^{8}$ For a $6 \mathrm{mg}$ film hematite, $F_{v}$ is calculated to be 0.21 using $\rho_{\text {true }}=5.3 \mathrm{gcm}^{-3}$. Hence, the value of $\mathrm{n}_{2}^{\prime}$ is calculated to be 1.6.

Table S3. Values of the molar extinction coefficients, $\varepsilon(\tilde{v})$, and penetration depth per reflection, $\mathrm{d}_{\mathrm{p}}$, used in surface coverage calculations at $\mathrm{pH} 7$

\begin{tabular}{|l|c|c|c|}
\hline Compound & $\begin{array}{c}\text { Wavenumber } \\
\left(\mathrm{cm}^{-1}\right)\end{array}$ & $\begin{array}{c}\varepsilon(\tilde{v}) \\
\left(\mathrm{cm}^{2} \text { molecule }^{-1}\right)\end{array}$ & $\mathrm{d}_{\mathrm{p}}(\tilde{v})(\mathrm{cm})$ \\
\hline iAs(V) & 875 & $8(2) \times 10^{-19}$ & $1.3(0.4) \times 10^{-4}$ \\
\hline DMA & 840 & $3(1) \times 10^{-19}$ & $1.3(0.4) \times 10^{-4}$ \\
\hline
\end{tabular}

Note: Numbers in parenthesis are $\pm \sigma$ from error propagation. 
Table S4. Saturation surface coverage calculations (molecule $\mathrm{cm}^{-2}$ ) after flowing $1.5 \mathrm{mM}$ arsenicals for $80 \mathrm{~min}$ at $\mathrm{pH} 7$ and the specified temperature.

\begin{tabular}{|l|c|l|}
\hline $\begin{array}{l}\text { Temperature } \\
\left({ }^{\circ} \mathrm{C}\right)\end{array}$ & iAs $(\mathrm{V})(\mathrm{ads})$ & DMA (ads) \\
\hline 5 & $1.2(0.3) \times 10^{13}$ & $1.7(0.6) \times 10^{13}$ \\
\hline 15 & $1.6(0.6) \times 10^{13}$ & $1.8(0.6) \times 10^{13}$ \\
\hline 25 & $1.7(0.6) \times 10^{13}$ & $1.8(0.6) \times 10^{13}$ \\
\hline 35 & $1.7(0.6) \times 10^{13}$ & $1.8(0.6) \times 10^{13}$ \\
\hline 50 & - & $1.9(0.6) \times 10^{13}$ \\
\hline
\end{tabular}

Note: Numbers in parenthesis are $\pm \sigma$ from error propagation in equation $\mathrm{S} 1$. 
Table S5: Temperature- and concentration-dependent observed initial adsorption rates $\left(r_{i, o b s}\left(\min ^{-}\right.\right.$ $\left.{ }^{1}\right)$ ) from fitting the slopes of the linear least squares fitting to the experimental data, which were linearized according to the Langmuir model. The $r_{i, o b s}$ are reported at a given $\tilde{v}$ assigned for adsorbed arsenate and DMA. The uncertainty in $r_{i, o b s}$ values is $15 \%$.

\begin{tabular}{cc|c|c|c|c|c|c|c|c|c|c|c}
\hline & \multicolumn{4}{c}{$875 \mathrm{~cm}^{-1}$} & \multicolumn{4}{c|}{$840 \mathrm{~cm}^{-1}$} & \multicolumn{5}{c}{$798 \mathrm{~cm}^{-1}$} \\
\cline { 2 - 13 }$\left(\begin{array}{c}\left.{ }^{\circ} \mathrm{C}\right) \\
\right.$\cline { 2 - 13 }\end{array} & \multicolumn{3}{c}{$[\mathrm{iAs}(\mathrm{aq})] / \mathrm{mM}$} & \multicolumn{3}{c}{$[\mathrm{DMA}(\mathrm{aq})] / \mathrm{mM}$} & \multicolumn{3}{c}{$[\mathrm{DMA}(\mathrm{aq})] / \mathrm{mM}$} \\
\hline 5 & 0.07 & 0.15 & 0.21 & 0.3 & 0.13 & 0.12 & 0.16 & 0.23 & 0.17 & 0.15 & 0.18 & 0.21 \\
\hline 15 & 0.06 & 0.17 & 0.23 & 0.38 & 0.14 & 0.16 & 0.18 & 0.26 & 0.15 & 0.17 & 0.2 & 0.25 \\
\hline 25 & 0.12 & 0.18 & 0.3 & 0.43 & 0.22 & 0.23 & 0.26 & 0.36 & 0.24 & 0.28 & 0.25 & 0.34 \\
\hline 35 & 0.11 & 0.15 & 0.32 & 0.45 & 0.20 & 0.24 & 0.23 & 0.36 & 0.17 & 0.23 & 0.19 & 0.29 \\
\hline 50 & - & - & - & - & 0.27 & 0.27 & 0.29 & 0.4 & 0.25 & 0.21 & 0.3 & 0.29 \\
\hline
\end{tabular}




\section{Cluster types 1}

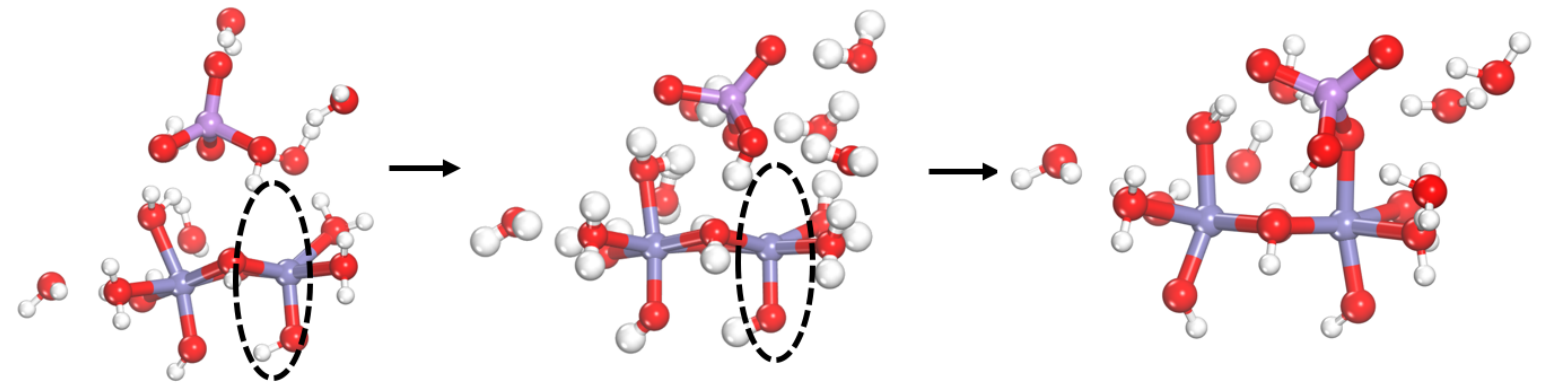



TS1b

TS1a

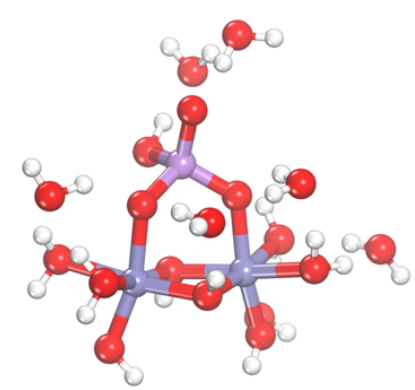

BB1

\section{Cluster types 2}
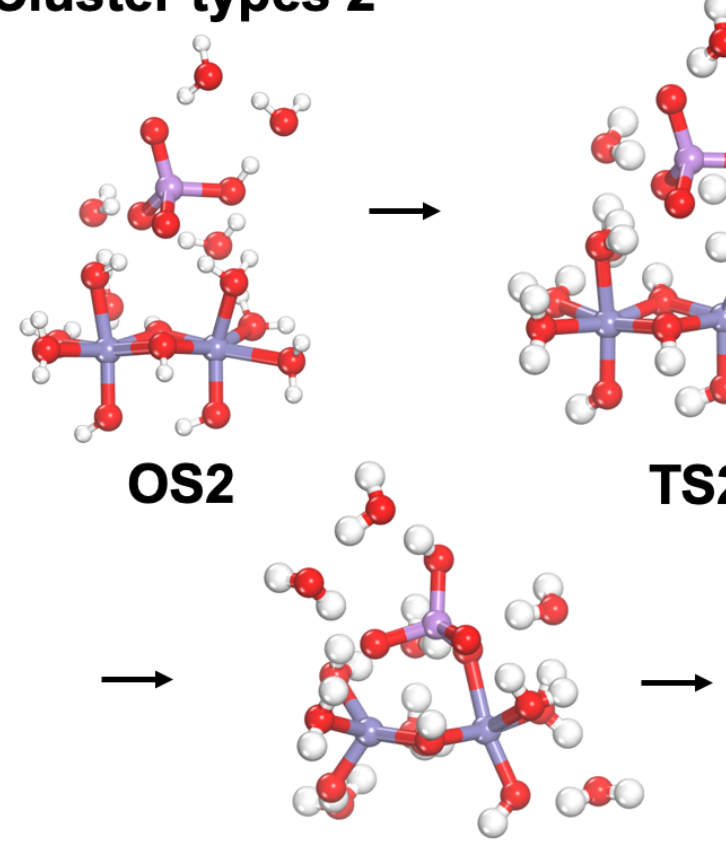

TS2b

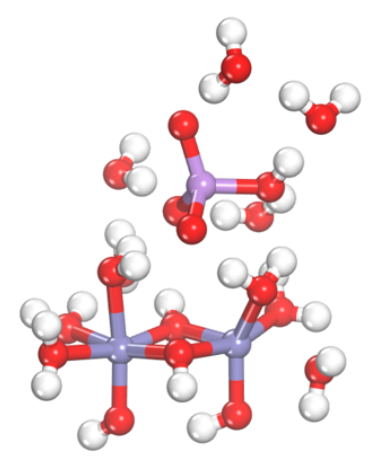

TS2a

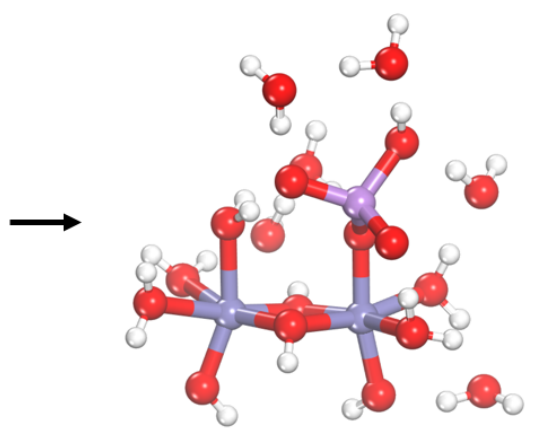

MM2

Figure S3: Optimized iAs-iron (oxyhydr)oxides clusters showing two types of hydrates clusters of OS, MM and BB complexes with explicit water molecules and an overall charge of zero. Also shown are optimized transition state clusters between OS and MM, and MM and BB. 
Table S6. Calculated frequencies $\left(\mathrm{cm}^{-1}\right)$ for DMA- and iAs Iron-(oxyhydroxide) complexes (cluster types 2), using B3LYP/6-311+G(d,p) with IEFPCM solvation and GD3BJ dispersion. Calculated IR intensities $\left(\mathrm{km} \mathrm{mole}^{-1}\right)$ are in parentheses. No scaling factor was used to correct for anharmonicity. The error bars on the calculated frequencies are on the order of a $3 \%$ for each frequency.

\begin{tabular}{|c|c|c|c|c|c|c|}
\hline Complex & $v(A s-O)$ & $v(\mathrm{As}-\mathrm{OFe})$ & $v(A s=0)$ & $v(\mathrm{As}-\mathrm{OH})$ & $v\left(\mathrm{As}-\mathrm{CH}_{3}\right)$ & $\rho\left(\mathrm{CH}_{3}\right)$ \\
\hline \multicolumn{7}{|l|}{ DMA } \\
\hline \multirow[t]{2}{*}{ OS2 } & $757(263)$ & & & & $588(39)$ & \\
\hline & 802 (204) & & & & $623(59)$ & \\
\hline \multirow[t]{2}{*}{ MM2 } & & 754 (614) & 819 (134) & & $592(17)$ & \\
\hline & & & & & $629(20)$ & \\
\hline \multirow[t]{3}{*}{ BB2 } & & 779 (102) & & & $585(183)$ & $851(53)$ \\
\hline & & $790(780)$ & & & $598(47)$ & 943 (91) \\
\hline & & 799 (128) & & & $630(60)$ & \\
\hline \multicolumn{7}{|c|}{ iAs $\left(\mathrm{HAsO}_{4}\right)$} \\
\hline \multirow[t]{2}{*}{ OS2 } & 763 (97) & & & 609 (44) & & \\
\hline & $\begin{array}{l}770(279) \\
784(128) \\
786(421) \\
846(619)\end{array}$ & & & & & \\
\hline \multirow[t]{3}{*}{ MM2 } & $803(176)_{s}$ & 781 (117) & & $656(250)$ & & \\
\hline & $831(450)_{\mathrm{as}}$ & $784(474)$ & & $686(79)$ & & \\
\hline & & $790(150)$ & & & & \\
\hline \multirow[t]{3}{*}{ BB2 } & & 755 (284) & 859 (463) & $691(172)$ & & \\
\hline & & $765(40)$ & & & & \\
\hline & & $782(716)$ & & & & \\
\hline
\end{tabular}


Table S7. Electronic energies of clusters shown in Figures 5 and S3 for the optimized DMA- and iAs-iron-(oxyhydr)oxides complexes calculated using B3LYP/6-311+ G(d,p) with IEFPCM solvation and GD3BJ dispersion models. DMA $=\left(\mathrm{CH}_{3}\right)_{2} \mathrm{AsO}_{2}{ }^{-}, \mathrm{iAs}=\mathrm{HAsO}_{4}{ }^{2-}$.

\begin{tabular}{|c|c|c|}
\hline Complexes & \begin{tabular}{|l|} 
Electronic Energy $\left(\mathrm{E}_{0}\right)$ \\
(Hartrees)
\end{tabular} & $\begin{array}{l}\text { Fe-OAs interatomic } \\
\text { distance }(\AA)\end{array}$ \\
\hline \multicolumn{3}{|l|}{ DMA cluster types 1 (Figure 5) } \\
\hline OS1 - DMA $\cdot\left(\mathrm{H}_{2} \mathrm{O}\right)_{6} \mathrm{Fe}_{2}(\mathrm{OH})_{5}\left(\mathrm{OH}_{2}\right)_{4}$ & -6138.01616 & 3.85 \\
\hline TS1a - DMA $\cdot\left(\mathrm{H}_{2} \mathrm{O}\right)_{6} \mathrm{Fe}_{2}(\mathrm{OH})_{5}\left(\mathrm{OH}_{2}\right)_{4}$ & -6138.00604 & 3.42 \\
\hline MM1 - DMA-Fe $2(\mathrm{OH})_{5}\left(\mathrm{OH}_{2}\right)_{4} \cdot\left(\mathrm{H}_{2} \mathrm{O}\right)_{6}$ & -6138.02346 & 3.63 \\
\hline TS1b - DMA- $\mathrm{Fe}_{2}(\mathrm{OH})_{5}\left(\mathrm{OH}_{2}\right)_{4} \cdot\left(\mathrm{H}_{2} \mathrm{O}\right)_{6}$ & -6138.01837 & 2.98 \\
\hline BB1 - DMA-Fe $2(\mathrm{OH})_{5}\left(\mathrm{OH}_{2}\right)_{3} \cdot\left(\mathrm{H}_{2} \mathrm{O}\right)_{7}$ & -6138.02312 & 2.07 \\
\hline \multicolumn{3}{|l|}{ DMA cluster types 2 (Figure 5) } \\
\hline OS2 - DMA $\cdot\left(\mathrm{H}_{2} \mathrm{O}\right)_{6} \mathrm{Fe}_{2}(\mathrm{OH})_{5}\left(\mathrm{OH}_{2}\right)_{5}$ & -6138.00126 & 4.41 \\
\hline TS2a - DMA $\cdot\left(\mathrm{H}_{2} \mathrm{O}\right)_{6} \mathrm{Fe}_{2}(\mathrm{OH})_{5}\left(\mathrm{OH}_{2}\right)_{5}$ & -6137.99429 & 3.00 \\
\hline MM2 - DMA-Fe $2(\mathrm{OH})_{5}\left(\mathrm{OH}_{2}\right)_{4} \cdot\left(\mathrm{H}_{2} \mathrm{O}\right)_{6}$ & -6138.01397 & 2.06 \\
\hline TS2b - DMA- $\mathrm{Fe}_{2}(\mathrm{OH})_{5}\left(\mathrm{OH}_{2}\right)_{4} \cdot\left(\mathrm{H}_{2} \mathrm{O}\right)_{6}$ & -6138.00735 & 2.94 \\
\hline BB2 - DMA-Fe ${ }_{2}(\mathrm{OH})_{5}\left(\mathrm{OH}_{2}\right)_{3} \cdot\left(\mathrm{H}_{2} \mathrm{O}\right)_{7}$ & -6138.02294 & 1.94 \\
\hline \multicolumn{3}{|l|}{ iAs cluster types 1 (Figure S3) } \\
\hline OS1 - iAs $\cdot\left(\mathrm{H}_{2} \mathrm{O}\right)_{6} \mathrm{Fe}_{2}(\mathrm{OH})_{4}\left(\mathrm{OH}_{2}\right)_{5}$ & -6209.86454 & 4.40 \\
\hline TS1a1 - iAs $\cdot\left(\mathrm{H}_{2} \mathrm{O}\right)_{6} \quad \mathrm{Fe}_{2}(\mathrm{OH})_{4}\left(\mathrm{OH}_{2}\right)_{5}$ & -6209.85844 & 3.80 \\
\hline TS1a2 - iAs $\cdot\left(\mathrm{H}_{2} \mathrm{O}\right)_{6} \mathrm{Fe}_{2}(\mathrm{OH})_{4}\left(\mathrm{OH}_{2}\right)_{5}$ & -6209.85997 & 2.60 \\
\hline MM1 - iAs-Fe $2(\mathrm{OH})_{4}\left(\mathrm{OH}_{2}\right)_{5} \cdot\left(\mathrm{H}_{2} \mathrm{O}\right)_{6}$ & -6209.88672 & 2.00 \\
\hline TS1b1 - iAs-Fe $2(\mathrm{OH})_{4}\left(\mathrm{OH}_{2}\right)_{5} \cdot\left(\mathrm{H}_{2} \mathrm{O}\right)_{6}$ & -6209.87841 & 2.52 \\
\hline TS1b2 - iAs- $\mathrm{Fe}_{2}(\mathrm{OH})_{4}\left(\mathrm{OH}_{2}\right)_{5} \cdot\left(\mathrm{H}_{2} \mathrm{O}\right)_{6}$ & -6209.88010 & 3.02 \\
\hline BB1 - iAs- $\mathrm{Fe}_{2}(\mathrm{OH})_{4}\left(\mathrm{OH}_{2}\right)_{4} \cdot\left(\mathrm{H}_{2} \mathrm{O}\right)_{6}$ & -6209.88481 & 2.02 \\
\hline \multicolumn{3}{|l|}{ iAs cluster types 2 (Figure S3) } \\
\hline OS2 - iAs $\cdot\left(\mathrm{H}_{2} \mathrm{O}\right)_{6} \mathrm{Fe}_{2}(\mathrm{OH})_{4}\left(\mathrm{OH}_{2}\right)_{6}$ & -6209.86482 & 4.19 \\
\hline TS2a - iAs $\cdot\left(\mathrm{H}_{2} \mathrm{O}\right)_{6} \mathrm{Fe}_{2}(\mathrm{OH})_{4}\left(\mathrm{OH}_{2}\right)_{5}$ & -6209.85684 & 3.09 \\
\hline MM2 - iAs- $\mathrm{Fe}_{2}(\mathrm{OH})_{4}\left(\mathrm{OH}_{2}\right)_{5} \cdot\left(\mathrm{H}_{2} \mathrm{O}\right)_{6}$ & -6209.87941 & 2.03 \\
\hline TS2b - iAs- $\mathrm{Fe}_{2}(\mathrm{OH})_{4}\left(\mathrm{OH}_{2}\right)_{4} \cdot\left(\mathrm{H}_{2} \mathrm{O}\right)_{6}$ & -6209.86347 & 3.52 \\
\hline BB2 - iAs-Fe $2(\mathrm{OH})_{4}\left(\mathrm{OH}_{2}\right)_{4} \cdot\left(\mathrm{H}_{2} \mathrm{O}\right)_{6}$ & -6209.90010 & 2.02 \\
\hline
\end{tabular}



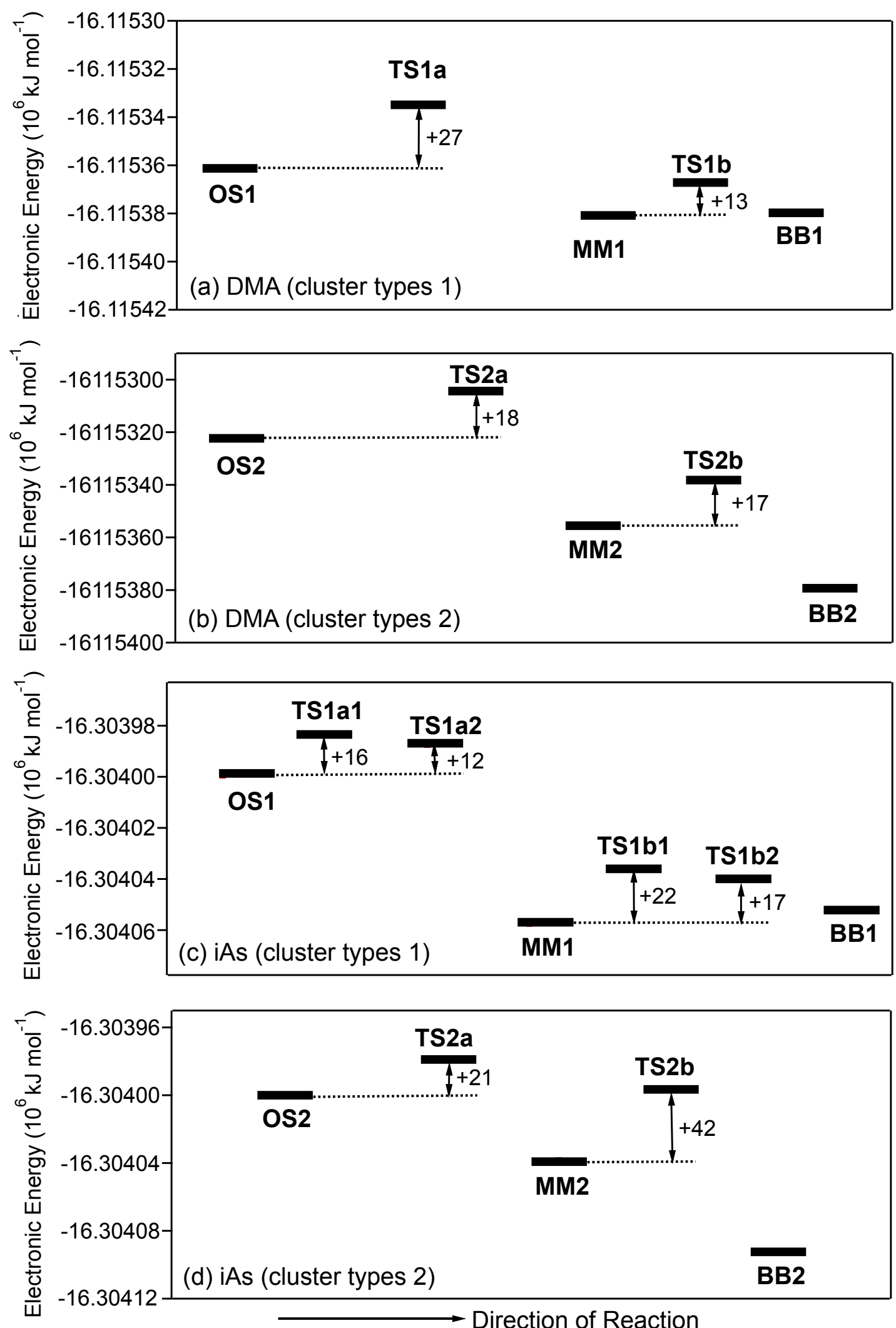

Figure S4: Electronic energies of the DMA and iAs clusters studied here along with transition states and activation energy barriers associated with transitioning from one complex to the next. 


\section{References}

(1) Dove, P.; Rimstidt, J., The solubility and stabilithy of scorodite. Amer. Mineral. 1985, 70, 838-844.

(2) Wu, J.-Z.; Ho, P. C., Speciation of inorganic and methylated arsenic compounds by capillary zone electrophoresis with indirect uv detection. Application to the analysis of alkali extracts of as2s2(realgar) and as2s3(orpiment). J. Chromat. A 2004, 1026, (1-2), 261-270.

(3) Barron, V.; Torrent, J., Surface hydroxyl configuration of various crystal faces of hematite and goethite. J. Coll. Inter. Sci. 1996, 177, 407-410.

(4) Situm, A.; Rahman, M. A.; Goldberg, S.; Al-Abadleh, H. A., Spectral characterization and surface complexation modeling of organics on hematite nanoparticles: Role of electrolytes in the binding mechanism. Environ. Sci. Nano 2016, 3, 910-926.

(5) Mitchell, W.; Goldberg, S.; Al-Abadleh, H. A., In-situ atr-ftir and surface complexation modeling studies on the adsorption thermodynamics of mono- and di-substituted organoarsenicals on iron-(oxyhydr)oxides. J. Coll. Inter. Sci. 2011, 358, (2), 534-540.

(6) Depalma, S.; Cowen, S.; Hoang, T. N.; Al-Abadleh, H. A., Adsorption thermodynamics of p-arsanilic acid on iron (oxyhydr)oxides: In-situ atr-ftir studies. Environ. Sci. Technol. 2008, 42, (6), 1922-1927.

(7) Lefevre, G., In situ fourier-transform infrared spectroscopy studies of inorganic ions adsorption on metal oxides and hydroxides. Adv. Coll. Inter. Sci. 2004, 107, 109-123.

(8) Lide, D. R., Crc handbook of chemistry and physics. Taylor \& Francis: Boca Raton, 20122013; Vol. 93. 